\title{
Por uma nova consciência eclesial: Uma leitura teológico-pastoral a luz da Lumen Gentium
}

\author{
Orientador: Cesar Augusto Kuzma \\ Mestrando: James Luiz Girardi \\ Área de Concentração: Teologia Sistemático-Pastoral \\ Linha de Pesquisa: Fé e Cultura
}

Esta dissertação busca fazer uma leitura da nova consciência eclesial numa mudança de época na reflexão teológica do Magistério da Igreja, especificamente nos capítulos I e II da Lumen Gentium e de alguns teólogos que se ocupam do assunto. Nestas fontes, encontra-se grande parte da reflexão sobre a eclesiologia do Vaticano II. Elas podem oferecer elementos para superar alguns obstáculos que dificultam uma nova consciência eclesial para os tempos atuais. A pesquisa desenvolveu-se pelo método analítico das fontes. O Concílio Vaticano II propiciou uma virada eclesiológica.Ele é Considerado o Concílio da Igreja, pois sua intenção era de preparar a Igreja para os tempos modernos. Pensar uma Igreja inserida na atualidade. O que foi fundamental para a eclesiologia aparece no capítulo II da Lumen Gentium, o Povo de Deus que antecede o capítulo que fala da Hierarquia. A comunhão que une a todos numa mesma vocação cristã. Todos os batizados fazem parte igualmente do povo de Deus. Continuar com o ensino do Concílio Vaticano II e a reflexão teológica que se sucedeu logo após o concílio nos ajudará a aprofundar a nova consciência necessária para hoje.

Palavras-chave: Consciência eclesial; Vaticano II; Povo de Deus. 